\title{
Bacteriophytochromes in anoxygenic photosynthetic bacteria
}

\author{
Eric Giraud · André Verméglio
}

Published online: 10 September 2008

(C) Springer Science+Business Media B.V. 2008

\section{Erratum to: Photosynth Res (2008) 97:141-153}

DOI 10.1007/s11120-008-9323-0

On page 147 of the original publication, last paragraph, it is incorrectly stated that PYP has been found so far only in photosynthetic bacteria. Genome sequencing has revealed the presence of PYP genes in various non-photosynthetic bacteria (see for example the review by Van der Horst et al.

\section{Reference}

Van der Horst MA, Key J, Hellingwerf K (2007) Photosensing in chemotrophic, non-phototrophic bacteria: let there be light sensing too. Trends in Microbiology 15:554-562

The online version of the original article can be found under doi:10.1007/s11120-008-9323-0.

\section{E. Giraud}

Laboratoire des Symbioses Tropicales et Méditerranéennes, IRD, CIRAD, AGRO-M, INRA, UM2, TA A-82/J,

Campus de Baillarguet, 34398 Montpellier Cedex 5, France

A. Verméglio $(\square)$

CEA, DSV, IBEB, Lab Bioenerget Cellulaire,

Saint-Paul-lez-Durance 13108, France

e-mail: avermeglio@cea.fr

A. Verméglio

CNRS, UMR Biol Veget \& Microbiol Environ,

Saint-Paul-lez-Durance 13108, France

A. Verméglio

Aix-Marseille Université, Saint-Paul-lez-Durance 13108, France 